${ }^{3}$ Medical Physics Department, Greater Poland Cancer Centre, Poznan, Poland

${ }^{4}$ Department of Nuclear Medicine, Affidea Poznan, Poland

${ }^{5}$ Chair and Department of Electroradiology, University of Medical Science, Poznan, Poland

\title{
Review of nuclear medicine methods applied in diabetology
}

\section{ABSTRACT}

The aim of this paper is to present the most relevant clinical applications of positron emission tomography/ /computed tomography, scintigraphy and single photon emission tomography with different radiotracers allowing to visualize e.g. glucose metabolism, amino acids metabolism, receptor density or inflammation and infections in diabetology. (Clin Diabetol 2019; 8, 6: 303-309)

Key words: diabetology, positron emission tomography, nuclear medicine, inflammation, scintigraphy

\section{Introduction}

According to data provided by the Central Statistical Office, it is estimated that in Poland there are more than 2.1 million people with both diabetes types and in 2016, there were 659 new cases and 2,517 407 medical consultations provided in diabetology clinics [1]. Nuclear medicine uses the properties of radioactive isotopes to visualize the various physiological processes taking place in the body. Positron emission tomography/computed tomography (PET/CT) and scintigraphy, the extension of which is single photon

Address for correspondence:

dr n. med. Paulina Cegła

Zakład Medycyny Nuklearnej, Wielkopolskie Centrum Onkologii

e-mail: paulina.cegla@gmail.com

Clinical Diabetology 2019, 8, 6, 303-309

DOI: $10.5603 /$ DK.2019.0028

Received: 26.07.2019

Accepted: 18.10.2019 emission tomography/computed tomography (SPECT/ /CT) and three-phase scintigraphy (allowing to visualize the blood flow, tissue and bone phase of the examined area) are now the basic imaging methods used in nuclear medicine. In addition nuclear medicine techniques have been used in oncology (for example to determine the severity of the disease or to assess the response to the applied treatment), cardiology (for example for assessing myocardial perfusion or myocardial viability) and in neurology (i.e. for imaging a brain tumors and in neurodegenerative disease) [2].

The aim of this paper is to present the most important applications of PET/CT, SPECT/CT and three-phase scintigraphy and also to show the future directions which might have implications on management in diabetic patients.

\section{Scintigraphy}

Scintigraphy in an imaging technique that uses a gamma camera consisting of one or more detector heads to create a functional 3D distribution of a photon emitter radionuclide from the patient's body. The raw data for the reconstruction of spatial distribution are acquired as a series of discrete planar images at multiple angles over the longitudinal axis of the patient [2].

The main elements of the detector head are a collimator, a scintillation crystal and a photomultiplier (Fig. 1). The collimator creates a radionuclide image of the patient on the scintillation crystal, which converts gamma rays into light. The light is detected by photomultiplier tubes whose digital output is used to calculate the spatial coordinates of each scintillation event. The computer system is used for processing (reconstructing), storing and displaying images [3]. 


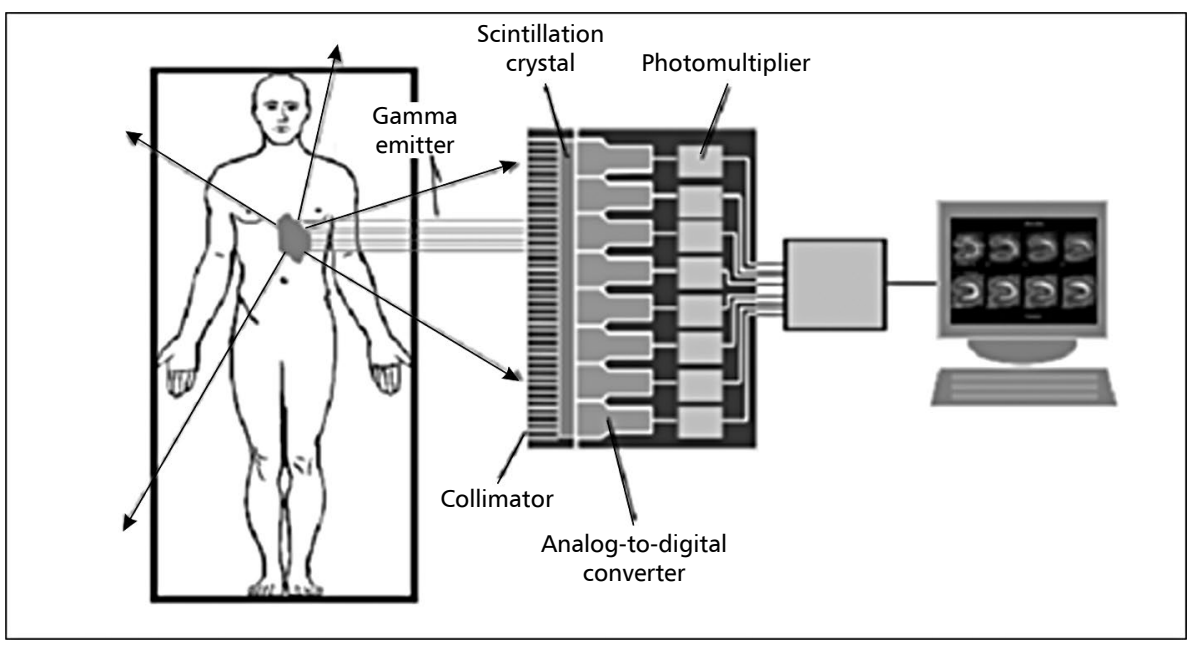

Figure 1. Scheme of a conventional gamma camera used in scintigraphy [3]

Whole body scan (WBS) with 99 metatable technetium $\left({ }^{99 \mathrm{~m} T c)}\right.$ labelled diphosphonates, e.g. methylene diphosphonate (MDP), hydroxyethylidene diphosphonate (HEDP) and hydroxymethylene diphosphonate (HMDP) are a useful tool for imaging malignant otitis externa and scintigraphy with labelled leukocytes, is the most commonly used techniques in inflammation and infection imaging. Infections in diabetology can be divided into frequent and specific ones. Frequent infections include: fungal infections, pulmonary tuberculosis, pneumonia, bacteremia, urinary tract infections, renal replacement infections (hemodialysis or continuous ambulatory peritoneal dialysis), skin and bone infections and diabetic foot infections [4]. Specific infections in diabetic patients include nasocerebral mucormycosis, malignant otitis external, emphysema, and emphysema cholecystitis [5-7].

\section{Diagnosis of diabetic foot}

Magnetic resonance imaging (MRI) is the method of choice in imaging diabetic foot infection and osteomyelitis [8], however, also radioisotope methods, including scintigraphy, are beginning to play a significant role in the diagnosis of this disease. Three-phase scintigraphy allows to obtain additional information on the vascularization of the examined area. The first phase of the study (blood flow) exposes increased blood circulation around the ongoing inflammatory process, while the second phase of the study (tissue phase) evaluates the volume of blood in the area. The last part of the study is the metabolic phase (delayed phase), which illustrates the increased accumulation of the radiotracer in the area in which increased osteoblastic activity is noted [4]. The image obtained with this technique does not allow differential diagnosis of fracture with Charcot neuro-osteoartropathy [9] due to low specificity (from 10-67\%, mean 40\%) [10], therefore, a modification of the study was introduced by adding $4^{\text {th }}$ phase after 24 hours from radiopharmaceutical administration. This is due to the fact that in the osteomyelitis, the accumulation of the radiotracer lasts for several hours, while in uninfected bones up to 4 hours. If in phase 4 the target-to-background ratio increases, this is the sufficient basis for confirmation of osteomyelitis [11], while the ratio of target-to-background with a point of 1.06 with $82 \%$ sensitivity and $92 \%$ specificity allows to diagnose osteoarthritis. Compared to standard threephase bone scintigraphy, adding $4^{\text {th }}$ phase increases the specificity of the method to $87 \%$ [12].

A significant improvement in the diagnosis of osteoarthritis has been observed with the use of labeled leukocytes (in vitro or in vivo), which show increased accumulation in inflammation. One of the most commonly used ligands labeled with ${ }^{99 \mathrm{~m} T c}$ is hexamethylpropylene amine oxime (HMPAO). The sensitivity and specificity of a static scintigraphic study using ${ }^{99 \mathrm{~m} T c-}$ -HMPAO is $90-93 \%$ and $86-100 \%$ respectively [13, 14], while the sensitivity and specificity for three-phase

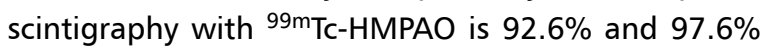
respectively in bone inflammation diagnosis [15].

Myocardial ischemia and myocardial infarction are much more common in patients with diabetes due to the asymptomatic course of cardiac complications in these patients, therefore, an appropriate strategy can have a key impact in the diagnosis of silent ischemia. Methoxyisobutylisonitrile (MIBI) labeled with ${ }^{99 \mathrm{~m}} \mathrm{Tc}$ is the most widely used radiotracer for assessing myocardial perfusion. The ${ }^{99 m}$ Tc-MIBI-SPECT/CT examination performed after exercise is characterized by high sensitivity and accuracy in the diagnosis of coronary 
heart disease. Authors from the International Atomic Energy Agency found that patients with diabetes more often suffer from myocardial ischemia and that diabetes was an independent factor associated with the occurrence of myocardial ischemia in relation to the control group. In addition, in people suffering from diabetes, myocardial ischemia was more frequent, visible in the electrocardiogram (ECG) picture during exercise, while no significant differences in detecting myocardial ischemia between the group of patients and the control group in ECG and ${ }^{99 \mathrm{~m} T c-M I B I-S P E C T / ~}$ /CT were found [16].

\section{Diabetic gastroparesis}

Gastroparesis is defined as a delay in gastric emptying and one of causes is a complication of diabetes mellitus [17]. According to various sources diabetic gastro-

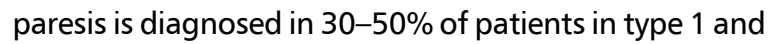
2 diabetes and is more common in female than in men [18]. Diabetic gastroparesis might be divided into two types: reversible (when normal gastric motility returns after glycemic normalization) and irreversible (when after normalization of glycemia there is still incorrect gastric motility function). There are several methods to measure gastric emptying, however scintigraphy with ${ }^{99 \mathrm{~m}} \mathrm{Tc}$ is the gold standard. This is a noninvasive imaging techniques which involves measuring the rate of gastric emptying with the meal (usually 2 slices of

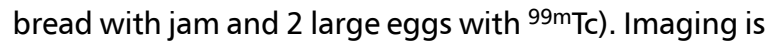
performed at baseline, 30 minutes, 1 hour, 2 hours and 4 hours after the meal. The 1 hour postprandial scan is use to visualize the rapid gastric emptying while the 2- and 4-hour scans are used in delayed visualization of gastric emptying. Extension of gastric emptying by $10 \%$ over a 4-hour norm in the case of men allows to diagnose a diabetic gastroparesis, while in women the prolonged time must exceed $25 \%$. Other radionuclide methods which allow to measure gastric emptying include breath testing utilizes a nonradioactive carbon isotope $\left({ }^{13} \mathrm{C}\right)$ bound with spirulina or octanoic acid which is mixed with eggs, absorbed from small bowel and metabolized by the liver. Then it is expelled from lungs and measured in exhale breath. Specificity and sensitivity of this method is similar to the scintigraphy with ${ }^{99 \mathrm{~m} T c}(80 \%$ and $86 \%$, respectively), however in a patients with concurrent lungs, pancreatic or liver disease, this examination might give a false positive results. That's why scintigraphy with ${ }^{99 \mathrm{mT}} \mathrm{Tc}$ is the gold standard in diagnosis of diabetic gastroparesis $[17,18]$.

\section{Other infections}

In case of malignant otitis external (MOE) ${ }^{99 \mathrm{~m} T c-}$ -MDP study is helpful in differential diagnosis from simple external otitis by the increased accumulation of the radiotracer in the temporal bone and the base of the skull. ${ }^{99 \mathrm{~m}} \mathrm{Tc}$ bone scan is more sensitive than other imaging techniques like CT scans or radiography and allows for earlier diagnosis of MOE, because it shows functional changes which occur earlier than anatomic ones. Additionally, a scintigraphy with gallium 67 has been proposed to assess the response to treatment in patients with MOE [19].

Diagnosis of kidney diseases with labeled dimercaptosuccinic acid ${ }^{99 \mathrm{~m}} \mathrm{Tc}$ ( ${ }^{99 \mathrm{~m} T c-D M S A)}$ allows to determine the distribution of kidney function, the focal changes in the parenchyma, to determine the shape and position of the kidneys or to assess the transplanted kidney. The degree of radiopharmaceutical accumulation is dependent on the functional state of the proximal tubules and blood flow [20]. In case of acute pyelonephritis, there are three types of abnormal results: regional, multifocal and the diffused one. As a result of scar formation in the course of chronic pyelonephritis, a reduced uptake of the radiopharmaceutical (usually in a triangular shape, the base directed towards the kidney surface) is observed in the damaged part of the kidney parenchyma [21, 22].

Scintigraphy with ${ }^{99 \mathrm{~m} T c}$ labeled iminodiacetic acid (IDA) allows to assess the function of the liver and bile ducts and imaging of a gallbladder. Presence of gallbladder in ${ }^{99 m}$ Tc-IDA scintigraphy suggest cystic duct patency and absence - obstruction. This is very important imaging method, especially in type 2 diabetes, because allows to differentiate non-alcoholic fatty liver disease (NAFDL) with non-alcoholic steatohepatitis (NASH), hepatitis and liver cirrhosis. NAFDL is associated with insulin resistance and obesity which are one of the most common causes of type 2 diabetes. The most commonly used are 3 ligands: trimetyloacetanilido acid (MBrIDA), hepatoiminodiacetic acid (HIDA) and diisopropyliminodiacetic acid (DISIDA) [23]. This imaging shows a higher sensitivity compared to ultrasound ( $86 \%$ to $48 \%$ respectively), while the combination of both techniques increases the sensitivity to $90 \%$ [24]. The secondary function of the ${ }^{99 m}$ Tc-IDA examination is the liver uptake rate of the radiopharmaceutical (in a well-functioning liver within a few minutes a marked decrease in radioactivity in the bloodstream and visibility of the liver parenchyma is noticed) and the rate of passage of the radiopharmaceutical from the bile ducts to the small intestine (properly functioning gallbladder becomes visible between 15 and 30 minutes of the study, while at the end of the acquisition the radiopharmaceutical should be visible in the bowel projection). Decreased radiotracer uptake from the bloodstream suggests damage to hepatocyte function, delaying bile 
excretion to the intestines is an evidence of impaired bile duct patency, and total intestinal uptake after 24 hours from radiopharmaceutical administration - on arthritis or total obstruction of the bile ducts $[22,23]$.

\section{Positron emission tomography (PET)}

The physics of imaging in positron emission tomography (PET) is based on the emission of positrons from nuclei with excessive amounts of protons. Positron moves a short distance in the patient's tissue and annihilates on contact with electron. The effect of the annihilation of the electron-positron pair is the generation of two photons with $511 \mathrm{keV}$ that are emitted in opposite directions. Due to the nature of the photon pair emission process, a single detector system used in SPECT imaging does not provide the appropriate geometry for the simultaneous detection of two photons [24], thus a typical PET scanner consists of many rings of scintillation detectors. Due to the registration of photon coincidences, a collimator is not required, which significantly increases the sensitivity of PET in comparison with the gamma camera [2]. When both photons from an annihilation are absorbed simultaneously (in coincidence) in two opposing detectors, a count will be made (Fig. 2). The photon registration process looks the same as in the gamma camera. As a result of annihilation of positrons of the radionuclide with electrons in tissue, the emission of photon pair of $511 \mathrm{keV}$ in opposite directions takes place. Registration of photons on a scintillation crystal within a given time interval means coincidence detection. Further processing of the recorded signal using a photomultiplier allows to determine the spatial coordinates of each count [25]. Using an electronic system consisting of a photomultiplier tube and an analog-digital converter, an electrical signal from a scintillation in the detector's crystal after interaction with the photon is recorded. After the acquisition, first the acquired images are corrected for damping and scattering, etc., and then processed mathematically to obtain transverse images of the layers of the studied area [26].

One of the most commonly used radiopharmaceuticals in the PET technique is the fluorine-labeled glucose analogue ( $\left.{ }^{18} \mathrm{~F}-\mathrm{FDG}\right)$. Due to the metabolic vector used, this radiopharmaceutical, in addition to uptake in cells showing increased request/needs for glucose (including cancer cells), also accumulates in inflammatory lesions. The sensitivity of the ${ }^{18} \mathrm{~F}$-FDG-PET/CT study decreases with the increase glucose level (should not exceed $200 \mathrm{mg} / \mathrm{dL} ; 11.1 \mathrm{mmol} / \mathrm{l}$ ), hence new, alternative markers for ${ }^{18} \mathrm{~F}$-FDG that can be used in diabetic patients, regardless of the level of glucose in the blood are needed.

For neuroendocrine tumors imaging (including insulinoma and glucagonoma), which has the presence of somatostatin receptors, the PET/CT study with ${ }^{68} \mathrm{Ga}$-DOTA-peptides is used. Several derivatives of ${ }^{68} \mathrm{Ga}$ labeled somatostatin are available, which differ in their affinity for various somatostatin receptor subtypes. ${ }^{68} \mathrm{Ga}$-DOTA-TOC, ${ }^{68} \mathrm{Ga}$-DOTA-NOC, ${ }^{68} \mathrm{Ga}$-DOTA-TATE and ${ }^{68} \mathrm{Ga}-\mathrm{DOTA}-\mathrm{LAN}$ they bind to the somatostatin receptor subtype 2 (SSTR2), showing different affinity for other receptor subtypes SSTR: ${ }^{68} \mathrm{Ga}$-DOTA-NOC and ${ }^{68} \mathrm{Ga}$-DOTA-LAN to SSTR 3 and $5,{ }^{68} \mathrm{Ga}$-DOTA-TOC connects also with SSTR5 (however with less affinity than DOTA-NOC), whereas ${ }^{68} \mathrm{Ga}$-DOTA-TATE shows the highest affinity for the SSTR2 receptor among all peptides $[27,28]$.

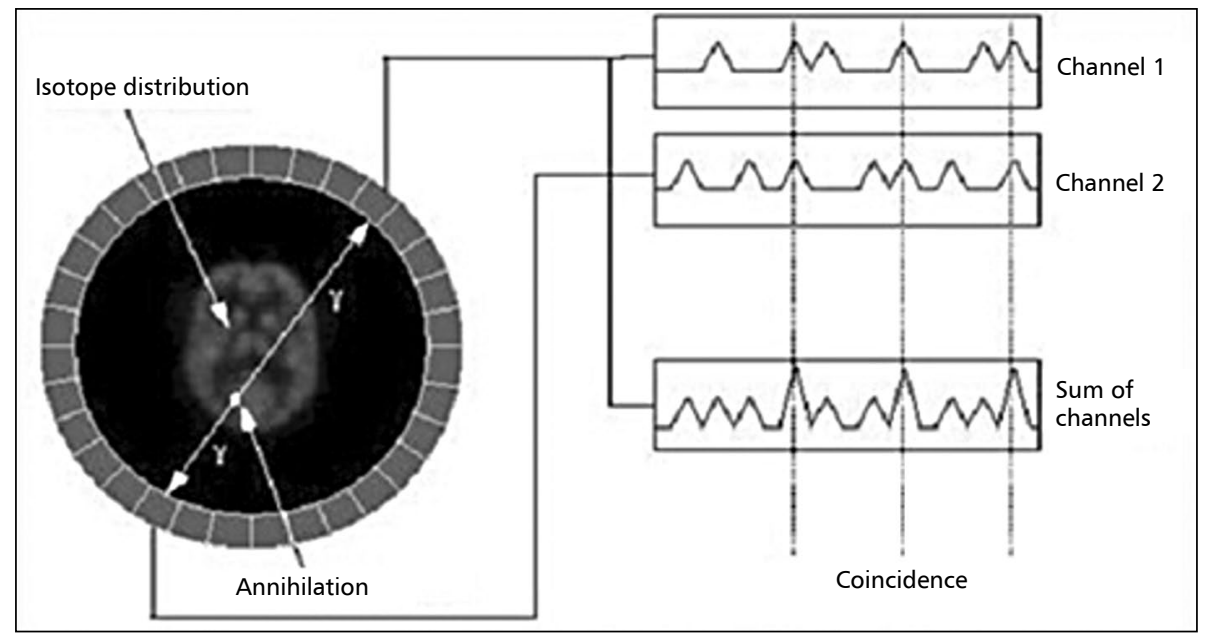

Figure 2. Schematic diagram of a coincidence [25] 
Another radioisotope used in the diagnosis of insulinomas in children and infants is Fluorine-labeled dihydroxyphenylalanine ( ${ }^{18} \mathrm{~F}$-DOPA) [28]. Congenital hyperinsulinism is one of the most common causes of hypoglycaemia in newborns, among which two histological subtypes are distinguished: diffused (about 95-98\% of cases) and focal one. In half of infants requiring pancreatic resection, a curable focal form is found, and the performance of the ${ }^{18} \mathrm{~F}$-DOPA-PET/ /CT study allows for differential diagnosis of diffused and focal forms and the selection of an appropriate treatment method. Identification and exact location of the lesion in the case of focal hyperinsulinism allow resection limited to the focal point leading to a reduction of postoperative complications in treated children including diabetes and pancreatic enzyme substitution $[29,30] .{ }^{18} \mathrm{~F}-\mathrm{DOPA}-\mathrm{PET} / \mathrm{CT}$ study diagnose $75-100 \%$ focal changes [31].

One of the latest developments in nuclear medicine is the ability to label glucagon-like peptide- 1 receptor (GLP-1R) present in insulinoma. It was found that no other peptide receptor showed such high levels of expression in this type of tumors (frequency $>90 \%$ and density $8.133 \mathrm{dpm} / \mathrm{mg}$ tissue) [32]. PET/CT study with labeled gal 68 exendin-4 ( ${ }^{68} \mathrm{Ga}$-DOTA-exendin-4 PET/CT) showed that it is a sensitive diagnostic tool for detecting insulinoma tumors and locating latent tumors [33, 34]. Sensitivity of ${ }^{68} \mathrm{Ga}-\mathrm{DOTA}$-exendin-4 PET/CT exceeds conventional imaging methods (including computed tomography, MRI and transesophageal ultrasound) in detecting this types of tumors [35].

\section{Future directions}

A huge development took place in the production of radiopharmaceuticals for imaging bacterial infections. ${ }^{64} \mathrm{Cu}-\mathrm{MAb}$ 1D9, ${ }^{89} \mathrm{Zr}-\mathrm{MAb}$ 1D9, ${ }^{68} \mathrm{Ga}-\mathrm{UBI} 29-41$, $\mathrm{m}$-[18F]-fluoro-PABA, [methyl-11C]-D-methionie, ${ }^{18} \mathrm{~F}-$ -FDS, ${ }^{18} \mathrm{~F}$-fluoromaltose and ${ }^{18} \mathrm{~F}$-fluoromaltohexaose are one of the most recent radiopharmaceuticals used in PET/CT studies for imaging bacterial infections.

MAb (1D9) against Staphylococcus antigen A or a gram-positive bacterium has been recently labeled with a copper 64 isotope $\left({ }^{64} \mathrm{Cu}, \mathrm{T}_{1 / 2}=12.7 \mathrm{~h}\right)$ and zirconium $\left.89{ }^{89} \mathrm{Zr}_{1} \mathrm{~T}_{1 / 2}=78.4 \mathrm{~h}\right)$ and evaluated in PET on mice. MAb $1 \mathrm{D} 9$ clearly targeted $S$. aureus on the $3^{\text {rd }}$ day after the radiotracer injection, the ratio of abscess to background was 2-3 times higher than in control groups and comparable to the results obtained from the ${ }^{18}$ F-FDG-PET study. MAb 1 D9 also showed nonspecific uptake in $E$. coli infections and lipopolysaccharide-induced sterile inflammations, attributed to the binding of MAb to Fc receptors present in the membrane of the cell-infiltrating macrophages [36-38].
Trimethoprim (TMP) is an organic chemical compound, a chemotherapeutic agent that inhibits bacterial dihydrofolic acid reductase, an enzyme in the synthesis of DNA and the folate pathway of most bacterial species (including Gram-positive and Gram-negative), mycobacteria and some parasites. As a PET radiotracer, ${ }^{18} \mathrm{~F}$-fluoropropylotrimethoprim (18F-FPTMP) showed a high uptake in bacteria, in in vitro studies performed in mice and a high ratio of abscesses to muscles, which ranged between 2 and 3 in mice. However, due to the high activity in the liver, gallbladder and intestines, imaging of infections in the abdomen appears to be limited [39].

Antimicrobial peptides (AMP) designed to quickly kill a wide spectrum of pathogens, including Gram-positive and Gram-negative bacteria, fungi, parasites and even capsular viruses. $\mathrm{UBI}_{29-41}$ most commonly labelled with ${ }^{99 \mathrm{~m}} \mathrm{Tc}$, is a cationic synthetic particle derived from natural cationic vicbuicidin AMP $\left(\mathrm{UBI}_{1-59}\right)$ however, recently this ligand has been used for PET/CT studies in combination with ${ }^{68} \mathrm{Ga}$. Both PET analogues ${ }^{68} \mathrm{Ga}-\mathrm{NOTA}-\mathrm{UBI}_{29-41}$ and ${ }^{68} \mathrm{Ga}-\mathrm{NOTA}-\mathrm{UBI}_{31-38}$ showed comparable characteristics of uptake in infected femoral muscles in mice and rabbits. However $\mathrm{UBI}_{29-41}$ was also accumulated in yeast-induced infections, which reduces the specificity of the use of this marker to visualize only the bacterial infections $[40,41]$.

PET with a radiofluorinated analogue of $p$-aminobenzoic acid $m$-[18F]-fluoro-PABA, which is a substrate for the synthesis of folic acid in prokaryotic organisms, was performed on rats infected with methicillin or staphylococcus aureus. PET study with $m$-[18F]-fluoroPABA showed rapid uptake in bacterial infections (core to muscle ratio $\approx 8$ ) and low uptake in sterile inflammation (about nine times lower), which meant that this radiopharmaceutical can be considered as specific for imaging bacterial infections. $m$-[18F]-fluoro-PABA showed reduced uptake in tissues infected with Staphylococcus aureus treated with oxacillin, indicating the possibility of using this radiopharmaceutical also to monitor response to treatment [42].

Another substrate associated with the folic acid synthesis pathway is methionine, which has been studied in the context of Staphylococcus aureus and $E$. coli infection imaging. Based on the uptake in infected muscles in mice, a PET study with carbon-labeled $\left({ }^{11} \mathrm{C}\right)$ methyl-D-methionine was helpful in differentiating (at 6-9 times higher abscess to inflammation ratios) between active non-active $E$. coli and staphylococcus infection [43].

Siderophores, low molecular weight iron transporters, are used by most bacteria, fungi and some plants to remove iron from the environment, which is key 
because of many different metabolic processes. In PET studies siderophores are usually labelled with ${ }^{68} \mathrm{Ga}$. An in vivo study with ${ }^{68} \mathrm{Ga}$-labeled triacetylfusarinine $\left({ }^{68} \mathrm{Ga}-\right.$ -TAFC) performed on rats infected with $A$. fumigatus (Aspiroplasma), S. aureus and sterile inflammation in the thigh and lung muscles infection, showed increased radiotracer accumulation in $A$. fumigatus infected sites (ratio abscess to the background between 5.8 and 6.6). At the same time, there was also an increased uptake of the radiotracer in sterile inflammatory sites (although lower than in the case of $A$. fumigatus), while in tissues infected with $S$. aureus, no ${ }^{68} \mathrm{Ga}$-TAFC uptake was observed [44].

In the imaging of bacterial infections, [18F]-fluorosorbitol is also used ( $\left.{ }^{18} \mathrm{~F}-\mathrm{FDS}\right)$, sorbitol analogue, which is a substrate metabolized only by enterobacteria. It has been proven that ${ }^{18} \mathrm{~F}$-FDS-PET imaging is a promising diagnostic tool which helps to differentiate $E$. coli infections or a pneumonitis bacillus ( $K$. pneumoniae) with Gram-positive infection. $E$. coli infections can be adequately visualized with ${ }^{18} \mathrm{~F}$-FDS in mice, with uptake in infected tissues is about eight times higher than sterile inflammation. Additionally, ${ }^{18}$ F-FDS-PET after ceftriaxone antimicrobial therapy in $E$. coli infection showed that in infected tissues, radiotracer uptake is eight-fold lower for those treated with ceftriaxone. This showed that ${ }^{18} \mathrm{~F}-\mathrm{FDS}$ can be used in antimicrobial therapy monitoring [45].

Type 1 diabetes is characterized by the loss of $\beta$-cells in the islets of the pancreatic Langerhans, followed by a deficiency of insulin secretion in response to hyperglycaemia. The development of an in vivo test that would allow the assessment of $\beta$-cell mass (BCM) mass measurement would significantly increase the ability to track diabetes therapy. The $\beta$-cells and neurological tissues share common cellular receptors and transporters, therefore a study using brain radioligands for their ability to identify $\beta$-cells has been performed. The D2/D3 receptor agonist, radioligand ${ }^{11} \mathrm{C}-(+)$-propylhexahydro-naphthooxazin $\left({ }^{11} \mathrm{C}-\mathrm{PHNO}\right)$ was the only one showing high uptake in the pancreas with respect to the abdominal organs, such as the kidneys, liver and spleen. However, further in vitro and in vivo studies to determine the specificity of the D3 receptor for $\beta$-cells are indicated to introduce ${ }^{11} \mathrm{C}$-PHNO as a specific radiotracer used to measure BCM [46].

One of the most advantages of imaging in nuclear medicine is that it allows imaging of functional changes which usually occur much earlier than anatomical changes that can be visualized by standard imaging methods. All the new methods which are in the clinical trial phase, if will be approved for clinical use, might allow in earlier detection of changes, especially in the diagnosis of infection in diabetics, and thus less diabetic complications and better care for patients. Also early detection of changes which may suggest future diabetes development by using nuclear imaging modalities, will allow close control and better care of this group of patients.

\section{Conclusion}

Nuclear medicine plays a significant role in the diagnosis of infection and other diseases occurring in diabetic patients. The use of proper radiopharmaceuticals obtain accurate location and diagnosis of diseases, and the combination of nuclear medicine techniques with commonly used imaging methods in diabetic patients permits the implementation of appropriate treatment and its control.

\section{Conflict of interest}

All the authors declare no conflict of interest in the field covered by this paper.

\section{REFERENCES}

1. https://stat gov pl/infografiki-widzety/infografiki/infografikaswiatowy-dzien-walki-z-cukrzyca-14-listopada,46,2 html. (odwiedzone 21.04.2019).

2. Almakiewiz R, Szostak S, Birkenfeld B. Podstawy fizyki promieniowania. In: Birkenfeld B, Listewnik M (ed.). Medycyna nuklearna, obrazowanie molekularne. Wydawnictwo Pomorskiego Uniwersytetu Medycznego w Szczecinie, Szczecin 2011: 152-161.

3. Wernick MN, Aarsvold JN. Emission tomography. The fundamentals of PET and SPECT. San Diego: Elsevier Academic Press. 2004.

4. Peleg AY, Weerarathna T, McCarthy JS, et al. Common infections in diabetes: pathogenesis, management and relationship to glycaemic control. Diabetes Metab Res Rev. 2007; 23(1): 3-13, doi: 10.1002/dmrr.682, indexed in Pubmed: 16960917.

5. Kemper J, Kuijper EJ, Mirck PG, et al. Recovery from rhinocerebral mucormycosis in a ketoacidotic diabetic patient: a case report. J Laryngol Otol. 1993; 107(3): 233-235, doi: 10.1017/ s0022215100122716, indexed in Pubmed: 8509703.

6. Carfrae MJ, Kesser BW. Malignant otitis externa. Otolaryngol Clin North Am. 2008; 41(3): 537-549, doi: 10.1016/j.otc.2008.01.004, indexed in Pubmed: 18435997.

7. Bhansali A, Sridhar C, Choudhary S. Type 2 diabetes, emphysematous pyelonephritis and emphsematous cholecystitis. J Assoc Physicians India. 2004; 52: 124, indexed in Pubmed: 15656046.

8. Sella EJ. Current concepts review: diagnostic imaging of the diabetic foot. Foot Ankle INT. 2009; 30: 568-576.

9. Rajbhandari SM, Jenkins RC, Davies C, Tesfaye S. Charcot neuroarthropathy in diabetes mellitus. Diabetologia. 2002; 45: 1085-1096.

10. Keenan AM, Tindel NL, Alavi A. Diagnosis of pedal osteomyelitis in diabetic patients using current scintigraphic techniques. Arch Intern Med. 1989; 149: 2262-2266.

11. Alazraki N, Deries D, Datz F, et al. Value of 24-hour image (four phase bone scan) in assessing osteomyelitis in patients with peripheral vascular disease. J Nucl Med. 1985; 26: 711-717.

12. Israel O, Gips S, Jerushalmi J, et al. Osteomyelitis and soft-tissue infection: differential diagnosis with 24 hour/4 hour ratio of Tc-99m MDP uptake. Radiology. 1987; 163(3): 725-726, doi: 10.1148/radiology.163.3.3575722, indexed in Pubmed: 3575722. 
13. Blume P, Dey H, Daley $L$, et al. Diagnosis of pedal osteomyelitis with Tc-99m HMPAO labeled leukocytes. J Foot Ankle Sugr. 1997; 36(2): 120-126, doi: 10.1016/s1067-2516(97)80057-9.

14. Devillers A, Garin E, Polard JL, et al. Comparison of Tc-99m-labelled antileukocyte fragment Fab' and Tc-99m-HMPAO leukocyte scintigraphy in the diagnosis of bone and joint infections: a prospective study. Nucl Med Commun. 2000; 21(8): 747-753, doi: 10.1097/00006231-200008000-00008, indexed in Pubmed: 11039458.

15. Poirier JY, Garin E, Derrien C, et al. Diagnosis of osteomyelitis in the diabetic foot with 99mTC-HMPAO leukocyte scintigraphy combined with a ${ }^{99 \mathrm{~m} T c-M D P}$ bone scintigraphy. Diabetes Metab. 2002; 28: 485-490.

16. Hage FG, Lusa L, Dondi $M$, et al. IAEA Diabetes Investigators. Exercise stress tests for detecting myocardial ischemia in asymptomatic patients with diabetes mellitus. Am J Cardiol. 2013; 112(1): 14-20, doi: 10.1016/j.amjcard.2013.02.047, indexed in Pubmed: 23578350.

17. Farmer AD, Bruckner-Holt C, Schwartz S, et al. Diabetic Gastroparesis: Perspectives From a Patient and Health Care Providers. J Patient Cent Res Rev. 2019; 6(2): 148-157, doi: 10.17294/23300698.1689, indexed in Pubmed: 31414026.

18. Krzyżewska M, Maroszek P, Mrozikiewicz-Rakowska B, et al. Diabetic gastroparesis: do you know how to recognize and effectively treat? Diabet Klin. 2014; 3: 157-166.

19. Strashun AM, Najatheim M, Goldsmith SJ. Malignant external otitis: Elary scintigraphic detection. Radiology 1984; 150: 541-545.

20. Birkenfeld B, Kozłowska I, Listewnik M. Badania scyntygraficzne nerek. In: Birkenfeld B, Listewnik M (ed.). Medycyna nuklearna, obrazowanie molekularne. Wydawnictwo Pomorskiego Uniwersytetu Medycznego w Szczecinie, Szczecin 2011: 90-98.

21. Rossleigh MA. Scintigraphic imaging in renal infections. Q J Nucl Med Mol Imaging. 2009; 53: 72-77.

22. Elbl B, Birkenfeld B, Kozłowska I. Badania radioizotopowe przewodu pokarmowego. In: Birkenfeld B, Listewnik M (ed.). Medycyna nuklearna, obrazowanie molekularne. Wydawnictwo Pomorskiego Uniwersytetu Medycznego w Szczecinie, Szczecin 2011: 69-78.

23. Kalimi R, Gecelter GR, Caplin D, et al. Diagnosis of acute cholecystitis: sensitivity of sonography, cholescintigraphy and combined sonography-cholescintigraphy. J AM Coll Surg. 2001; 193: 609-613.

24. Saha G. Physics and radiobiology of nuclear medicine. 2006, doi: 10.1007/978-0-387-36281-6.

25. National Research Council and Institute of Medicine. Advancing Nuclear Medicine Through Innovation. Washington: The National Academies Press. 2007.

26. Fogelman I, Gnanasegaran G, Van de. Radionuclide and hybrid bone imaging. Springer-Verlag, Berlin 2013.

27. Antunes $P$, Ginj $M$, Zhang $H$, et al. Are radiogallium-labelled DOTA-conjugated somatostatin analogues superior to those labelled with other radiometals? Eur J Nucl Med Mol Imaging. 2007; 34(7): 982-993, doi: 10.1007/s00259-006-0317-x, indexed in Pubmed: 17225119.

28. Dziennik Urzędowy Ministra Zdrowia, Obwieszczenie Ministra Zdrowia z dnia 22 grudnia 2014 w sprawie ogłoszenia wykazu wzorcowych procedur radiologicznych z zakresu medycyny nuklearnej.

29. Ismail D, Hussain K. Role of 18F-DOPA PET/CT imaging in congenital hyperinsulinism. Rev Endocr Metab Disord. 2010; 11(3): 165-169, doi: 10.1007/s11154-010-9145-1, indexed in Pubmed: 20878481.

30. Buraczewska M, Brandt A, Kopacz K.E, Myśliwiec M. Znaczenie diagnostyki obrazowej wrodzonego hiperinsulinizmu u rodzeństwa. Endokrynol Ped. 2015; 14: 47-50.
31. Arnoux JB, Verkarre V, Saint-Martin C, et al. Congenital hyperinsulinism: current trends in diagnosis and therapy. Orphanet $J$ Rare Dis. 2011; 6: 63, doi: 10.1186/1750-1172-6-63, indexed in Pubmed: 21967988.

32. Körner M, Christ E, Wild D, et al. Glucagon-like peptide-1 receptor overexpression in cancer and its impact on clinical applications. Front Endocrinol (Lausanne). 2012; 3: 158, doi: 10.3389/ fendo.2012.00158, indexed in Pubmed: 23230431.

33. Antwi K, Fani M, Nicolas G, et al. Localization of Hidden Insulinomas with ${ }^{68} \mathrm{Ga}-\mathrm{DOTA}-E x e n d i n-4$ PET/CT: A Pilot Study. J Nucl Med. 2015; 56(7): 1075-1078, doi: 10.2967/jnumed.115.157768, indexed in Pubmed: 25999434.

34. Luo Y, Yu M, Pan Q, et al. 68Ga-NOTA-exendin-4 PET/CT in detection of occult insulinoma and evaluation of physiological uptake. Eur J Nucl Med Mol Imaging. 2015; 42(3): 531-532, doi: 10.1007/ s00259-014-2946-9, indexed in Pubmed: 25398421.

35. Luo Y, Pan Q, Yao S, et al. Glucagon-like peptide-1 receptor PET/ /CT with 68Ga-NOTA-Exendin-4 for detecting localized insulinoma: a prospective cohort study. J Nucl Med. 2016; 57(5): 715-720, doi: 10.2967/jnumed.115.167445, indexed in Pubmed: 26795291.

36. Wiehr S, Warnke P, Rolle AM, et al. New pathogen-specific immunoPET/MR tracer for molecular imaging of a systemic bacterial infection. Oncotarget. 2016; 7(10): 10990-11001, doi: 10.18632/ oncotarget.7770, indexed in Pubmed: 26934329.

37. Romero Pastrana F, Thompson JM, Heuker M, et al. Noninvasive optical and nuclear imaging of Staphylococcus-specific infection with a human monoclonal antibody-based probe. Virulence. 2018; 9(1): 262-272, doi: 10.1080/21505594.2017.1403004, indexed in Pubmed: 29166841.

38. Pickett JE, Thompson JM, Sadowska A, et al. Molecularly specific detection of bacterial lipoteichoic acid for diagnosis of prosthetic joint infection of the bone. Bone Res. 2018; 6: 13, doi: 10.1038/ s41413-018-0014-y, indexed in Pubmed: 29707402.

39. Sellmyer MA, Lee I, Hou C, et al. Bacterial infection imaging with [F]fluoropropyl-trimethoprim. Proc Natl Acad Sci U S A. 2017; 114(31): 8372-8377, doi: 10.1073/pnas.1703109114, indexed in Pubmed: 28716936.

40. Ocampo IZ, de Queiroz Souza Passos P, Ramirez de Carvalho L, et al. In vitro cytotoxic and genotoxic evaluation of peptides used in nuclear medicine (DOTATATE and Ubiquicidin) in CHO-K1 cells. Cytotechnology. 2016; 68(6): 2301-2310, doi: 10.1007/s10616016-0024-9, indexed in Pubmed: 27686814.

41. Carrasco-Hernandez J, SolÃs-Lara H, Altamirano-Ley J, et al. Measured human dosimetry of 68Ga-DOTA-UBI 29-41, a potential tracer for imaging bacterial infection processes. J Nucl Med. 2016; 57: 1020.

42. Zhang Z, Ordonez AA, Wang H, et al. Positron Emission Tomography Imaging with 2-[F]F- p-Aminobenzoic Acid Detects Staphylococcus aureus Infections and Monitors Drug Response. ACS Infect Dis. 2018; 4(11): 1635-1644, doi: 10.1021/acsinfecdis.8b00182, indexed in Pubmed: 30067329.

43. Neumann KD, Villanueva-Meyer JE, Mutch CA, et al. Imaging Active Infection in vivo Using D-Amino Acid Derived PET Radiotracers. Sci Rep. 2017; 7(1): 7903, doi: 10.1038/s41598-017-08415-x, indexed in Pubmed: 28801560.

44. Petrik $\mathrm{M}$, Zhai $\mathrm{C}$, Haas $\mathrm{H}$, et al. Siderophores for molecular imaging applications. Clin Transl Imaging. 2017; 5(1): 15-27, doi: 10.1007/ s40336-016-0211-x, indexed in Pubmed: 28138436.

45. Li J, Zheng H, Fodah R, et al. Validation of 2-F-fluorodeoxysorbitol as a potential radiopharmaceutical for imaging bacterial infection in the lung. J Nucl Med. 2018; 59(1): 134-139, doi: 10.2967/ jnumed.117.195420, indexed in Pubmed: 28848037.

46. Bini J, Naganawa M, Nabulsi N, et al. Evaluation of PET Brain Radioligands for Imaging Pancreatic $\beta$-Cell Mass: Potential Utility of C-(+)-PHNO. J Nucl Med. 2018; 59(8): 1249-1254, doi: 10.2967/ jnumed.117.197285, indexed in Pubmed: 29371405. 